\title{
Exploring infections as an aetiological agent of breast carcinoma
}

\author{
M.H.J. Ariyaratne MBBS(Col), MS(Col), FRCS(Eng), FRCS(Ed) 1 , M.H.J.D. Ariyaratne, MBBS $^{2}$ \\ 1 Head, Department of Clinical Sciences, General Sir John Kotalawela Defence Academy, Ratmalana. \\ 2 Demonstrator, Department of Microbiology, Faculty of Medical Sciences, University of Sri Jayewardenepura.
}

Key words: Breast cancer; Aetiology; Infections.

Breast cancer currently enjoys the position of being the commonest cancer in females worldwide [1] and indeed in Sri Lanka. In 2005 breast cancer contributed to $14.3 \%$ of all cancers reported islandwide and $25.4 \%$ of all female cancers [2]. Many aetiological factors have been discovered with a strong focus on hereditary forms of breast cancer [3]. However, these contribute only to $5-10 \%$ of breast cancers overall. Environmental, socio-economic, hormonal and radiation factors have also been shown to contribute to the aetiology. An emerging area of interest is the role of infectious agents in breast cancer aetiology.

The global burden of infectious agents causing cancer is 16$18 \%$ [4]. Most of these infection related cancers occur in developing countries and are due to treatable infections caused by Hepatitis B virus (HBV), Hepatitis C virus (HCV), Human Papilloma virus (HPV), Helicobacter pylori,Epstein Barr virus (EBV) and Cytomegalovirus (CMV).

The aim of this article is to give an overview of infectious agents linked to carcinomas and their association with breast cancer

\section{Viruses}

Viruses have long been linked to carcinoma. Epstein-Barr virus is known to cause nasopharyngeal carcinoma and Burkitt's lymphoma. HPV has been proved to be a causal agent in cervical carcinoma5. Most of these viruses have lytic and latent cycles. The genes expressed in the latent cycle allow these viruses to remain in certain cells and also set up an environment conducive to malignant change. Some of these genes can promote tumour growth. A recent study in Taiwan found the presence of genes of several viruses in breast cancer cells [6]. Therefore, it is rational to investigate a possible link between viruses and breast cancer.

Correspondence: Department of Clinical Sciences,

General Sir John Kotalawela Defence Academy,

Ratmalana.

Email-mhjari@gmail.com

\section{Epstein Barr Virus (EBV)}

This is a human herpes virus. It is a ubiquitous infection which commonly occurs in childhood. It replicates in the buccal and nasopharyngeal mucosa and is unique in its ability to transform its main target; the B-lymphocyte [5].

It is a prevalent infection in China and other parts of Asia. It is associated with nasopharyngeal carcinoma, Burkitt's lymphoma and Hodgkin's lymphoma in immunosuppressed individuals. However, an interesting fact is in spite of its worldwide prevalence the cancers linked to EBV show geographical specificity [7]. Nasopharyngeal carcinoma for example occurs mainly in China and other parts of South Asia whereas Burkitt's lymphoma is found mainly in Africa. This suggests that there are local factors which alter the carcinogenesis initiated by EBV. Malaria has been proven to be a cofactor in Burkitt's lymphoma [7]. Late exposure to EBV was found to be a risk factor in one study [8]. A study conducted in India [9] found significant expression of EBV DNA in breast cancer tissue compared to non-malignant breast tissue and also a higher immunological response. An Egyptian study found an association between EBV and invasive breast cancer and suggested that it may be involved in the aetiology [10]. Another study also revealed that EBV was frequently found in more aggressive breast cancer [11]. In the recent past it was discovered that EBV infections in-vitro of breast cancer cells would confer resistance to paclitaxel (taxol) and provoke overexpression of a multidrug resistance gene [12]. A possible carcinogenesis pathway was explored by a Taiwanese group which found that there was activation of HER2/HER3 signalling cascades by EBV genes expressed in breast carcinoma cells [13]. Studies have shown that the HER2/neu gene is amplified in 30\% of breast tumours and that this amplification is a significant predictor of overall survival and relapse in breast cancer [13].

The causal relationship between breast cancer and EBV is yet to be proven. A possible geographical relationship between EBV incidence and breast cancer incidence was explored by a French study which failed to show a correlation [14].

\section{Cytomegalovirus (CMV)}

This is also a herpes virus closely related to EBV [5]. Like EBV, CMV also establishes latent infection. CMV DNA has 
been detected in breast cancer cells and a persistent infection of breast epithelia by CMV has also been shown, suggesting that CMV is involved in the development of breast cancer [15] . Studies have concluded that an elevation in the serum CMV IgG precede the development of breast cancer and also late exposure to CMV increases the risk of breast cancer in older women [16]. CMV however has shown to be oncomodultory rather than oncogenic as it does not transform cells but affects signaling pathways [17]. Research conducted at the University of San Fransisco [18] to determine possible tumorigenesis of breast cancer, has found that cmvIL-10 secreted by CMV infected cells activates STAT 3 in breast cancer cells through phosphorylation causing them to become invasive or metastatic. Studies [17] have suggested that CMV can cause glioblastomas to become resistant to chemotherapy and therefore there is ongoing research to establish the value of offering antiviral therapy as an adjunct to chemotherapy in treating glioblastoma patients.

\section{Human Papilloma virus (HPV)}

Papilloma viruses cause warts on skin and genital regions. There are clear associations between the development of cervical cancer and HPV infection, especially HPV 16 \& 18 [5]. In most primary and metastatic cancer cells, the HPV genomes are present in integrated form (ie. within the host genome), and certain viral oncoprotein genes referred to as E6 and E7 are transcribed and translated. Integration occurs at different chromosomal locations and the E6 and E7 seem to be involved in transformation of epithelial cells and in maintenance of the transformed state, probably by binding to and inactivating tumor-suppressing cellular proteins concerned with regulation of the cell cycle. E6 is involved in turnover of p53 a tumor suppressor protein, and E7 binds and inactivates the retinoblastoma proteins [5]. Both of these activities are critical in HPV induced oncogenesis and result in genome instability, accumulation of oncogene mutations, uncontrolled cell growth and eventually cancer. Somatic mutations in the TP53 gene are much more common, occurring in approximately 20 percent to 40 percent of all breast cancer cases [19]. The evidence linking HPV to breast cancer is controversial. Many studies have suggested the possibility whereas many more refute it. Some studies have found HPV DNA using PCR but not with in-situ hybridization suggesting the possibility of HPV being linked to breast cancer [20]. More recent studies conducted in Switzerland and India have failed to show a link [21, 22]. All these studies have recommended larger epidemiological studies to be done in this area.

\section{Human Herpes virus 8 (HHV 8)}

HHV 8 is another herpes virus and causes Kaposi's sarcoma which is 300 times more common in patients with AIDS [5]. It is also seen in benign and malignant lymphomatous conditions, namely multicentric Castleman's disease and primary effusion lymphoma respectively. HHV 8 was found in one study to be more prevalent in breast cancer tissues than EBV [6]. HHV induced IL6 has been shown to have an effect on the proliferation of human cells especially the myeloma cell line [23]. IL6 has been shown to be significantly increased in breast cancer patients and further demonstrated to be a poor prognostic predictor in chemo-endocrine therapy and represents a poor prognostic predictor of metastasis [24, 25]. The evidence linking HHV 8 significantly to breast cancer however is still obscure.

\section{Mouse Mammary Tumour virus (MMTV)}

The Mouse Mammary Tumour Virus (MMTV) also known as the Bittner virus is a retrovirus which is transmitted via breast milk. Dr. John Joseph Bittner in 1936 forwarded a hypothesis that a milk factor causing breast cancer would be transmitted to the offspring of infected mice [26]. It has been subsequently shown that these mice develop breast tumours. This sparked interest in exploring the connection between this virus and human breast cancer. Studies have proven that MMTV indeed infects human breast cancer cells [27]. MMTV genes have been found in up to 38\% of sporadic breast cancer [28].

An important characteristic of the MMTV is that it has genes which are highly responsive to steroids and progestins [29]. This may explain MMTV gene expression in $62 \%$ of gestational breast cancer [30]. One study concluded that human cells were capable of being infected by MMTV and can also support replication. This study also identified a human breast cancer cell line BT-474 to be an invasive ductal carcinoma derived line which was shown to be susceptible to infection by and replication of MMTV [31]. More evidence linking MMTV to breast cancer was established by discovering that there is an elevated expression of TP53 gene in the presence of MMTV genes [32]. The possible transmission of MMTV from mother to offspring has been explored and was not found to be a risk factor [33, 34]. Another study has proposed the possibility of mouse to human transmission of the virus, based on the observation that worldwide, the incidence of breast cancer in a geographic area is proportional to the incidence of the mouse species Mus domesticus in that area [35]. Research is ongoing to establish causality once and for all.

\section{Hepatitis B virus (HBC) \& Hepatitis C virus (HCV)}

Hepatitis $B$ virus which is a DNA virus and Hepatitis $C$ virus which is a RNA virus cause chronic liver infection which can persist and cause hepatocellular carcinoma [5]. Recent studies have found chronic Hepatitis $\mathrm{C}$ infection to be associated with other types of cancer [36-38]. However, population based studies have given varying results; a Taiwanese study found that HCV was a risk factor for early onset breast cancer [39] while another study found that chronic HCV infection was not a promoter of breast cancer [40]. This is also an area still being investigated. 


\section{Bacteria}

Helicobacter pylori has been implicated in the pathogenesis of gastric and duodenal cancer. It is thought that the chronic infection triggers chronic inflammation leading to metaplasia, dysplasia and carcinoma5. There seems to be a paucity of studies linking bacteria to breast cancer aetiology. This area of interest cannot be ignored as cancers are now accepted to occur in the presence of chronic infections and inflammation [41]. The role of gut bacteria in breast cancer has been researched. It was found that infecting mice with Helicobactor hepaticus promotes mammary carcinoma in females and enhances intestinal adenoma multiplicity by a tumor necrosis factor a (TNFa)-dependent mechanism [42]. A recent study found that bacteria can cause breast cancer cells to become invasive due to bacterial peptidoglycans by increasing the activity of toll-like receptor 2 [43]. Other studies however are trying to explore the other side of the story; can bacterial infections confer protection from the development of breast cancer? One finding that may support this study showed that chronic antibiotic use increased the risk of breast cancer [44]. Another study concluded that the IL-10 feedback inhibitory loop which is important for inhibition and therefore regulation of immune homeostasis is lost due to improved personal hygiene and antibiotic use. This gives a possible explanation for the increase in breast cancer risk in developed countries and how immune response to bacterial infections can provide some degree of protection from cancer [45]. Trypanasoma cruzi infections have showed varying degrees of inhibitory action on in-vitro human breast cancer cells [46]. The exact role bacteria play in breast cancer pathogenesis is yet to be elucidated.

In summary looking at the current information, viruses seem to be the main form of infections connected to breast cancer aetiology. Bacterial infections or sometimes the lack of it may also be contributing towards the development of breast cancer. More work is required to better understand the complex interplay between infections and our immune system and ultimately their effect on breast cancer pathogenesis.

\section{References}

1. American Cancer Society. Breast Cancer Facts \& Figures 2011-2012. Atlanta:American Cancer Society, Inc.

2. Cancer Incidence Data:Sri Lanka Year 2001-2005Cancer Registry.National Cancer Control Programme

3. Jardines L, , Goyal S., Fisher P, Weitzel J, Royce M, Goldfarb SB, CANCER MANAGEMENT: 14TH EDITION Breast Cancer Overview: Risk Factors, Screening, Genetic Testing, and Prevention October 3, 2011

4. de Martel C, Ferlay J, Franceschi S, et al. Global burden of cancers attributable to infections in 2008: a review and synthetic analysis. Lancet Oncol 2012; published online May 9. DOI:10.1016/S1470-2045(12)70137-7.

5. Goering RV, Dockrell HM, Wakelin D et al. Mims' medical microbiology. 4th ed. Philadelphia, PA: Mosby Elsevier;

\section{8:205-209}

6. Tsai JH, Tsai CH, Cheng MH, Lin SJ, Xu FL, Yang CC. Association of viral factors with non-familial breast cancer in Taiwan by comparison with non-cancerous, fibroadenoma, and thyroid tumor tissues. J Med Virol. 2005 Feb;75(2):276-81

7. Joseph Pagano S, Blaser M, Buendia MA, Damaniad B, Khalili K, Raab-Traub N, Roizman B. Infectious agents and cancer: criteria for a causal relation. Seminars in Cancer Biology 14 (2004) 453-471.

8. Yasui Y, Potter JD, Stanford JL, Rossing MA, Winget MD, Bronner M, Daling J. Breast cancer risk and "delayed" primary Epstein-Barr virus infection. Cancer Epidemiol Biomarkers Prev. 2001 Jan;10(1):9-16.

9. Joshi D, Quadri M, Gangane N, Joshi R, Gangane N. Association of Epstein Barr virus infection (EBV) with breast cancer in rural Indian women. PLoS One. 2009 Dec 4;4(12):e8180.

10. Fawzy S, Sallam M, Awad NM. Detection of Epstein-Barr virus in breast carcinoma in Egyptian women. Clin Biochem. 2008 May;41(7-8):486-92. Epub 2008 Jan 3

11. Bonnet M, Guinebretiere JM, Kremmer E, Grunewald V, Benhamou E, Contesso G, Joab I. Detection of Epstein-Barr virus in invasive breast cancers. J Natl Cancer Inst. 1999 Aug 18;91(16):1376-81.

12. Arbach H, Viglasky V, Lefeu F, Guinebretiere JM, Ramirez V, et al. Epstein-Barr virus (EBV) genome and expression in breast cancer tissue: effect of EBV infection of breast cancer cells on resistance to paclitaxel (Taxol). J Virol. 2006;80:845-853

13. Lin JH, Tsai CH, Chu JS, Chen JY, Takada K, Shew JY . Dysregulation of HER2/HER3 signaling axis in Epstein-Barr virus-infected breast carcinoma cells. J Virol. 2007 Jun;81(11):5705-13. Epub 2007 Mar 21.

14. Fina F, Romain S, Ouafik L, Palmari J, Ben Ayed F, Benharkat S, Bonnier P, Spyratos F, Foekens JA, Rose C, Buisson M, Gérard H, Reymond MO, Seigneurin JM, Martin PM. Frequency and genome load of Epstein-Barr virus in 509 breast cancers from different geographical areas. Br J Cancer. 2001 Mar 23;84(6):783-90.

15. Harkins LE, Matlaf LA, Soroceanu L, Klemm K, Britt WJ, Wang W, Bland KI, Cobbs CS. Detection of human cytomegalovirus in normal and neoplastic breast epithelium. Herpesviridae. 2010; 1: 8.

16. Cox B, Richardson A, Graham P, Gislefoss RE, Jellum E and Rollag H. Cancer, cytomegalovirus and Epstein-Barr virus: a nested case-control study. British Journal of Cancer (2010) 102, 1665-1669

17. Karolinska Institute, Centre for Molecular Medicine, CMV infection in cancer.

http://cmm.ki.se/en/Research/Cardiovascular-and-MetabolicDiseases/Cell-and-Molecular-Immunology/Cia/Ourresearch/CMV-infection-in-cancer/ Accessed 31/7/2012

18. Oseguera CV,Spencer JV .Role of human cytomegalovirus in breast cancer. Herpesvirus Research Laboratory, Department 
of Biology, University of San Francisco. Unpublished data.

19. The US National Library of medicine, Genetics. TP53 http://ghr.nlm.nih.gov/gene/TP53. Accessed 31/07/2012

20. Di Lonardo A, Venuti A, Marcante ML .Human papillomavirus in breast cancer. Breast Cancer Res Treat. 1992;21(2):95-100.

21. Hedau S, Kumar U, Hussain S, Shukla S, Pande S, Jain N, Tyagi A, Deshpande T, Bhat D, Mir MM, Chakraborty S, Singh YM, Kumar R, Somasundaram K, Bharti AC, Das BC. Breast cancer and human papillomavirus infection: No evidence of HPV etiology of breast cancer in Indian women. BMC Cancer 2011, 11:27

22. Lindel K, Forster A, Altermatt HJ, Greiner R, Gruber G. Breast cancer and human papillomavirus (HPV) infection: no evidence of a viral etiology in a group of Swiss women. Breast. 2007 Apr;16(2):172-7. Epub 2006 Nov 7.

23. Human Herpesvirus Type 8 Interleukin-6 Homologue Is Functionally Active on Human Myeloma Cells By Renate Burger, Neipel F, Fleckenstein B, Savino R, Ciliberto G, Kalden JR, Gramatzki M. Blood; 1998 91: 1858-1863

24. Zhang GJ, Adachi I. Serum interleukin-6 levels correlate to tumor progression and prognosis in metastatic breast carcinoma. Anticancer Res. 1999 Mar-Apr;19(2B):1427-32

25. Lyon DE, McCain NL, Walter J, Christine Schubert C. Cytokine Comparisons Between Women With Breast Cancer and Women With a Negative Breast Biopsy. Nurs Res. 2008; 57(1): 51-58.

26. Wikipedia-Mouse Mammary tumour virus. http://en.wikipedia.org/wiki/Mouse_mammary_tumour_viru. Accessed 01/08/2012

27. Indik S, Günzburg WH, Brian Salmons B, Rouault F.Mouse Mammary Tumor Virus Infects Human Cells. Cancer Res August 1, 2005 65; 6651

28. Wang Y, Holland JF, Bleiweiss IJ, Melana S, Liu X, Pelisson I, Cantarella A, Stellrecht K, Mani S, Pogo BG. Detection of mammary tumor virus env gene-like sequences in human breast cancer. Cancer Res. 1995 Nov 15;55(22):5173-9.

29. Ham J, Thomson A, Needham M, Webb P, Parker M. Characterization of response elements for androgens, glucocorticoids and progestins in mouse mammary tumour virus. Nucleic Acids Res. 1988 June 24; 16(12): 5263-5276.

30. Wang Y, Melana SM, Baker B, Bleiweiss I, Fernandez-Cobo M, Mandeli JK, Holland JF,Pogo BGT . High prevalence of MMTV-like env gene sequences in gestational breast cancer. Medical Oncology Volume 20, Number 3 (2003), 233-236.

31. Lasfargues EY, Coutinho WG, Dion AS. human breast tumor cell line (BT-474) that supports mouse mammary tumor virus replication. In Vitro Cellular \& Developmental Biology - Plant Volume 15, Number 9 (1979), 723-729.

32. Lawson JS, Tran DD, Ford C,Rawlinson WD. Elevated Expression of the Tumor Suppressing Protein p53 is Associated with the Presence of Mouse Mammary TumorLike env Gene Sequences (MMTV-like) in Human Breast
Cancer. Breast Cancer Research and Treatment Volume 87, Number 1 (2004), 13-17.

33. Ekbom A, Hsieh CC, Trichopoulos D, Yen YY, Petridou E, Adami HO. Breast-feeding and breast cancer in the offspring. Br J Cancer. 1993 Apr;67(4):842-5.

34. Titus-Ernstoff L, Egan KM, Newcomb PA, Baron JA, Stampfer M, Greenberg ER, Cole BF, Ding J, Willett W, Trichopoulos D. Exposure to breast milk in infancy and adult breast cancer risk. J Natl Cancer Inst. 1998 Jun 17;90(12):921-4.

35. Stewart TH, Sage RD, Stewart AF, Cameron DW. Breast cancer incidence highest in the range of one species of house mouse, Mus domesticus. Br J Cancer. 2000 Jan;82(2):446-51.

36. Kose S, Olmezoglu A, Gozaydin A, Ece G. Seroprevalence of Hepatitis B and C among Oncology Patients in Turkey. J Health Popul Nutr. 2011 December; 29(6): 652-655.

37. Schöllkopf C, Smedby KE, Hjalgrim H, Rostgaard K, Panum I, Vinner L, Chang ET, Glimelius B, Porwit A, Sundström C, Hansen M, Adami HO, Melbye M. Hepatitis C infection and risk of malignant lymphoma. Int J Cancer. 2008 Apr 15;122(8):1885-90.

38. El-Serag H, Engels EA, Landgren O,Chiao E, Henderson L, Amaratunge HC, Giordano TP. Risk of Hepatobiliary and Pancreatic Cancers Following Hepatitis C Virus Infection. A Population-based Study of U.S. Veterans. Hepatology. 2009 January; 49(1): 116-123.

39. Su FH, Chang SN, Chen PC, Sung FC, Su CT, Yeh CC. Association between chronic viral hepatitis infection and breast cancer risk: a nationwide population-based case-control study. BMC Cancer. 2011 Nov 24;11:495.

40. Larrey D, Bozonnat MC, Kain I, Pageaux GP, Assenat E.Is chronic hepatitis $\mathrm{C}$ virus infection a risk factor for breast cancer? World J Gastroenterol. 2010 August 7; 16(29): 36873691.Published online 2010 August 7.

41. Coussens LM, Werb Z. Inflammation and cancer. Nature. 2002 December 19; 420(6917): 860-867.

42. Rao VP, Poutahidis, Ge Z, Nambiar PR,Boussahmain C,Wang YY, Horwitz BH,Fox JG,Erdman SE. Innate Immune Inflammatory Response against Enteric Bacteria Helicobacter hepaticus Induces Mammary Adenocarcinoma in Mice. Cancer Res August 1, 2006 66;

43. Xie W,Huang Y,Xie W,Guo A,Wu W. Bacteria Peptidoglycan Promoted Breast Cancer Cell Invasiveness and Adhesiveness by Targeting Toll-Like Receptor 2 in the Cancer Cells. PLoS One. 2010; 5(5): e10850.Published online 2010 May 26.

44. Ness RB, Cauley JA. Antibiotics and Breast Cancer-What's the Meaning of This? JAMA. 2004;291(7):880-881

45. Rao VP, Poutahidis T,Fox JG, Erdman SE. Breast Cancer: Should Gastrointestinal Bacteria Be on Our Radar Screen? Cancer Res February 1, 2007 67; 847

46. Sheklakova LA, Kallinikova VD, Karpenko LP.Genetic heterogeneity of Trypanosoma cruzi and its direct anticancer effect in cultured human tumor cells. Bull Exp Biol Med. 2003 Jan;135(1):89-92. 